\title{
Holocene Phytolith Record at Picea glehnii Stands on the Dorokawa Mire in Northern Hokkaido, Japan
}

\author{
Tatsuichiro Kawano*1, a , Hikaru Takahara*1, Toshie Nomura*2, \\ Hideaki Shibata*3 , Shigeru Uemura*3, Naoko Sasaki*4 \\ and Takahito Yoshioka*4
}

\begin{abstract}
Phytolith analysis was applied to clarify a vegetation history at Picea glehnii stands on the Dorokawa Mire, northern Hokkaido. Phytolith assemblages from surface samples and Holocene deposits from the mire are used to clarify the stand-scale vegetation history, with special focus on the dynamics of Gramineae, which includes dwarf bamboo, and the establishment of P. glehnii stands on the mire. The phytolith records during the early-Holocene ( $c a .12,000$ to $10,000 \mathrm{cal} \mathrm{BP})$ indicate the distribution of Pooideae-dominated vegetation, which reflects the cool climate. Phragmites (reed) dominated vegetation from the early to mid-Holocene ( $c a .10,000$ to 5,000 cal $\mathrm{BP})$ suggests wet conditions like low-moor. The reed was replaced by dwarf bamboo at $c a$. 5,000 cal BP, although the distribution of dwarf bamboo was scattered. At $c a$. 1,500 cal BP, dwarf bamboo increased abruptly and has been sustained to the present. Also, Pinaceae type phytoliths began to occur continuously at ca. 1,000 cal BP. Taking into account the relationship between modern vegetation and modern phytolith assemblages on the mire, the occurrence of the Pinaceae type phytoliths from the sediment samples indicates the existence of $P$. glehnii in the study sites. On the basis of these results, $P$. glehnii stands with dense undergrowth of dwarf bamboo would have been established in the study sites on the mire by $c a .1,000 \mathrm{cal} \mathrm{BP}$ at least.
\end{abstract}

Keywords : dwarf bamboo, Holocene, phytoliths, Picea glehnii stands, surface samples

\section{Introduction}

Picea glehnii dominated stands with dense undergrowth of dwarf bamboo are established on the Dorokawa Mire, which covers the drainage basin of the Dorokawa River in northern Hokkaido. On the other hand, mixed forests composed of some conifers and hardwood trees (Abies sachalinensis, Quercus crispula etc.) are widespread on the mountain slopes of the area. In general, $P$. glehnii forests are established on specific sites. Tatewaki (1943) classified P. glehnii forests into six habitat types: "mire", "volcanic ash and gravel", "sand dunes", "serpentinite substrate", "conglomerate" and "remains of fire disturbance" types. According to the habitat types, the P. glehnii stands on the Dorokawa Mire are classified as a "mire" type.

Received October 5, 2006. Accepted July 14, 2007.

*1 Graduate School of Agriculture, Kyoto Prefectural University. 1-5 Hangi-cho, Shimogamo, Sakyo-ku, Kyoto, 606-8522, Japan.

*2 Graduate School of Agriculture, Kyoto Prefectural University. 1-5 Hangi-cho, Shimogamo, Sakyo-ku, Kyoto, 606-8522, Japan (Present address : Tsunashima, Aokijima-cho, Nagano, 381-2206, Japan).

*3 Northern Forestry and Development Office, Field Science Center for Northern Biosphere, Hokkaido University. 250 Tokuda, Nayoro, 096-0071, Japan.

*4 Research Institute for Humanity and Nature. 457-4 Motoyama, Kamigamo, Kita-ku, Kyoto, 603-8047, Japan.

*a Corresponding author : kawano@uf.kpu.ac.jp 
The main vegetation changes in Hokkaido during the Holocene have been regionally traced mainly through pollen records (e.g. Tsukada and Nakamura, 1988 ; Igarashi et al., 1993 ; Igarashi, 1994 ; Morita, 2001). However, except some palynological studies (Igarashi and Takahashi, 1985 ; Igarashi et al., 2001 ; Morita, 2001), the dynamics of P. glehnii forests have not yet been clarified. In addition, dwarf bamboo, which is a Sasa species, currently forms a dense undergrowth in $P$. glehnii stands on the Dorokawa Mire. It is well known that the dwarf bamboo undergrowth has negative effects on the growth of tree seedlings (Nakashizuka, 1988 ; Hiura et al., 1996 ; Narukawa and Yamamoto, 2002). Therefore, this dwarf bamboo has great effects on the regeneration and vegetation structure of forests. Thus, to make clear the vegetation dynamics on the Dorokawa Mire, clarification of the dynamics of the dwarf bamboo is indispensable. However, there is little data about the dynamics of dwarf bamboo in palaeovegetation, because the identification of Gramineae, which includes dwarf bamboo species, by pollen is restricted to the family level. On the other hand, phytolith analysis is well known as an alternative technique available for reconstruction of the vegetation history of dwarf bamboo (Kariya et al., 2004 ; Sasaki et al., 2004 ; Sase et al., 2004).

Phytoliths are siliceous microscopic particles found within and among the cellular tissue of many plants. The dwarf bamboo accumulates a large amount of $\mathrm{SiO}_{2}$ in and between their cells. Therefore, phytolith analysis is a very useful tool for reconstructing the vegetation history of dwarf bamboo. In addition, some studies have shown that Pinaceae species, which include $P$. glehnii, produce distinctive leaf phytoliths (Klein and Geis, 1978 ; Kondo et al., 2003). Moreover, phytoliths are resistant to decomposition in a sedimentary environment and their dispersion is shorter than that for pollen grains (Kondo and Sase, 1986). Therefore, the application of phytolith analysis for sediment samples provide a detailed basis for local vegetation reconstruction.

In this paper, we report the Holocene vegetation history with a special focus on the establishment of $P$. glehnii stands. We also report on the dynamics of vegetation composed of Gramineae, which includes dwarf bamboo, on the Dorokawa Mire based on a phytolith analysis conducted on modern and fossil assemblages.

\section{Materials and methods}

\section{Study area}

The Dorokawa Mire is located in the Uryu Experimental Forest of Hokkaido University in Moshiri, the northern part of Hokkaido, and lies about $290 \mathrm{~m}$ above sea level (Fig. 1). The average annual temperature at Moshiri Station of the Uryu Experimental Forest is about $4^{\circ} \mathrm{C}$, and the annual precipitation is $1,137 \mathrm{~mm}$ (Field Science Center for Northern Biosphere, Hokkaido University, Forest Research Station Database during 2005, unpublished data). At present, conifer stands composed of $P$. glehnii and hardwood stands composed mainly of Fraxinus mandshurica var. japonica and Ulmus davidiana var. japonica are established on the mire. In addition, Sasa senanensis, dwarf bamboo, forms a dense undergrowth in these stands. In this study, surface samples and core samples were collected from forest stands in the eastern part of the Dorokawa Mire.

\section{Surface samples for modern analogue}

Several previous studies reported that the phytolith assemblages from surface samples correspond to modern vegetation (Kondo, 1988 ; Eguchi, 1998 ; Kawano et al., 2006). The relationship between modern phytolith assemblages and modern vegetation is indispensable for the reconstruction of past vegetation. In this study, in order to make clear the differences of phytolith assemblages between $P$. glehnii stands and hardwood stands, a total of ten surface samples were collected from the P. glehnii stands (DRS $3,12,17,18,19)$ and the hardwood stands (DRS 4, $13,14,15,21)$ located on the Dorokawa Mire (Fig. 1 and Table 1). Also, to evaluate the distance of phytolith dispersion from a stand margin of P. glehnii, another six samples were collected by $10 \mathrm{~m}$ intervals along a $50 \mathrm{~m}$ transect from the margin of a P. glehnii stand (stand height about $20 \mathrm{~m}$ ) to dwarf bamboo grassland. The first one of these six samples was collected just below the crown of one of the margin of $P$. glehnii stand. Other five were from open dwarf bamboo grassland. The top five centimeters of 
the $\mathrm{A}_{0}$ humic horizon (except litter horizon) of each soil sample were collected for analysis of the phytoliths.

\section{Core samples}

Two core samples (UDA1 and UDA2) were collected in P. glehnii stands, where the surface samples were collected (Fig. 1). The UDA1 site is located in a small open area $(c a .10 \mathrm{~m}$ in diam- eter) covered by sedges and grasses, which is situated in the $P$. glehnii stand. The UDA1 site is surrounded mainly by P. glehnii and Sasa senanensis. The UDA2 site is located in $P$. glehnii stand with dense dwarf bamboo understory, and is about $100 \mathrm{~m}$ from the UDA1 site. Tree density and basal area of $P$. glehnii are 541 trees/ha and $21.4 \mathrm{~m}^{2} /$ ha, respectively, and the

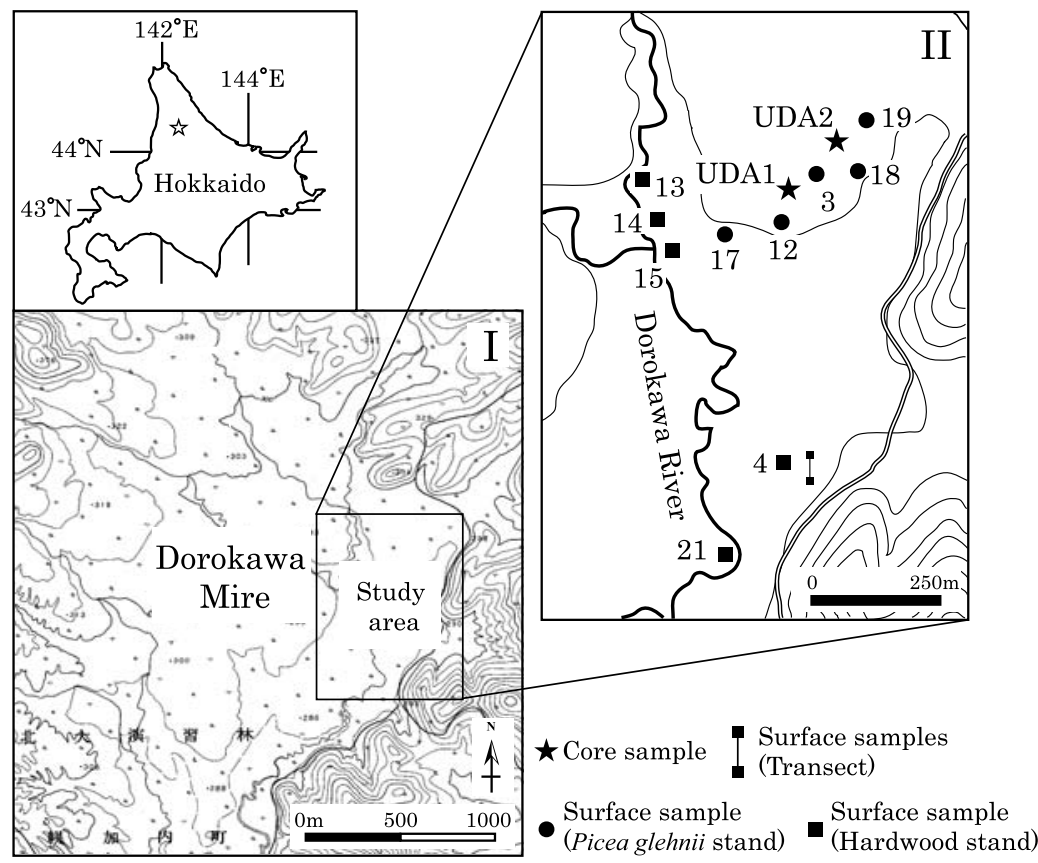

Fig. 1 Location of study sites

Numbers beside the solid circles and squares are the sample numbers of the modern assemblages (DRS series) used in this study. Maps I and II are based on a $1: 25,000$ scale topographic map "Fukinodai” published by the Geographical Survey Institute of Japan.

Table 1 Coverage (\%) of major plant species in each plot where the modern samples were obtained

\begin{tabular}{|c|c|c|c|c|c|c|}
\hline \multirow[b]{2}{*}{ Plot } & \multicolumn{5}{|c|}{ Tree species } & \multirow[b]{2}{*}{$\begin{array}{c}\text { Sasa } \\
\text { senanensis }\end{array}$} \\
\hline & $\begin{array}{c}\text { Picea } \\
\text { glehnï }\end{array}$ & $\begin{array}{c}\text { Abies } \\
\text { sachalinensis }\end{array}$ & $\begin{array}{c}\text { Fraxinus } \\
\text { mandshurica } \\
\text { var. japonica }\end{array}$ & $\begin{array}{c}\text { Ulmus } \\
\text { davidiana } \\
\text { var. japonica }\end{array}$ & $\begin{array}{c}\text { Betula } \\
\text { platyphylla } \\
\text { var. japonica }\end{array}$ & \\
\hline$\overline{\text { DRS3 }}$ & 35 & $\cdot$ & $\cdot$ & $\cdot$ & $\cdot$ & 100 \\
\hline DRS12 & 30 & * & - & • & + & 100 \\
\hline DRS17 & 30 & . & - & $\cdot$ & 5 & 90 \\
\hline DRS18 & 20 & + & - & • & + & 100 \\
\hline DRS19 & 30 & + & $\cdot$ & - & + & 100 \\
\hline DRS4 & - & - & 30 & 10 & - & 100 \\
\hline DRS21 & - & - & 20 & 40 & - & 100 \\
\hline DRS13 & + & • & 15 & • & + & 80 \\
\hline DRS14 & + & + & 15 & • & 5 & 100 \\
\hline DRS15 & . & $\cdot$ & 20 & + & 10 & 100 \\
\hline
\end{tabular}


coverage of dwarf bamboo is $100 \%$ within a 30 $m$ radius of the UDA2 site.

These two core samples were collected by a thinwall sampler $(7.5 \mathrm{~cm}$ diameter). Twentysix subsamples were analyzed in the $196 \mathrm{~cm}$ length profile of the UDA1 core. A peaty clay horizon was found in the profile from the bottom to a $182 \mathrm{~cm}$ depth. The profile above 182 $\mathrm{cm}$ is peat horizons. Thirty-one subsamples were also analyzed in the $258 \mathrm{~cm}$ length profile of the UDA2 core. Silt and peaty clay horizons were described in the profile from the bottom to a $250 \mathrm{~cm}$ depth. The profiles above $250 \mathrm{~cm}$ are mainly peat horizons.

\section{Chronology of the cores}

For the date control, AMS radiocarbon dating was carried out using macro-plant remains and organic matter. Three radiocarbon dates were obtained from the upper $200 \mathrm{~cm}$ depth of the UDA1 core and six radiocarbon dates from the upper $259 \mathrm{~cm}$ depth of the UDA2 core (Table 2). The radiocarbon dates at the $200 \mathrm{~cm}$ depth of the UDA 1 core and at the $259 \mathrm{~cm}$ depth of the UDA2 core were $6,980 \pm 40$ yrs BP $(7,816 \mathrm{cal} \mathrm{BP}$ of median calibrated age) and $10,160 \pm 25 \mathrm{yrs}$ BP $(11,850$ cal BP of median calibrated age), respectively. AMS radiocarbon datings of four samples were carried out by Beta Analytic Inc. (Beta) and other five samples by H. Kitagawa (Nagoya University) in the W.M. Keck Carbon Cycle Accelerator Mass Spectrometry Laboratory (UCIAMS). These AMS ${ }^{14} \mathrm{C}$ dates were cali- brated with the program CALIB 5.0.1 (Stuiver et al., 2005) using the IntCal04 calibration data set (Reimer et al., 2004).

Two types of tephra layers were found in the profiles between the 17 and $18 \mathrm{~cm}$ depth of the UDA1 core and between the 14 and $15 \mathrm{~cm}$ depth of the UDA2 core. The volcanic ashes correspond to Ma-b $(980 \pm 100$ yrs BP : Katsui et al., 1975) or B-Tm (AD937 : Fukusawa et al., 1998) and Ta-a (AD1739: Soya, 1972) tephra, respectively (Table 3). Range of the refractive index of volcanic grasses from $14-15 \mathrm{~cm}$ depth of the UDA2 core indicated the three types of tephra (Ta-a, Ma-b and B-Tm). However, almost volcanic grass shards (about $83 \%$ of count number of grass shard) from this layer were corresponded to the Ta-a tephra (Table 3). Therefore, the layer was recognized as Ta-a tephra falling horizon. The petrographical data of each tephra sample were measured by Kyoto Fission-Track Co. Ltd.

In this study, the age of each horizon of both the UDA1 and UDA2 cores were estimated from the age-depth curves, which were described using the calibrated radiocarbon dates and tephrochronological dates obtained from each core (Fig. 2). The average value (5,097 cal BP) at the UDA2 core was calculated using three median calibrated ages (from 131 to $133 \mathrm{~cm}$ horizons) at $2 \sigma$ calibrated age ranges and applied for the age-depth curve.

\section{Phytolith analysis}

The extraction of phytoliths from the sur-

Table 2 AMS ${ }^{14} \mathrm{C}$ dates for UDA1 and UDA2 cores

\begin{tabular}{|c|c|c|c|c|c|c|c|}
\hline Site & $\begin{array}{c}\text { Depth } \\
\text { (cm) }\end{array}$ & Material & $\begin{array}{l}{ }^{14} \mathrm{C} \text { age } \\
\text { (yrs BP) }\end{array}$ & $\begin{array}{c}2 \sigma \text { calibrated } \\
\text { age ranges } \\
(\text { cal BP })\end{array}$ & $\begin{array}{c}\text { Median } \\
\text { calibrated } \\
\text { age (cal BP) }{ }^{* 1}\end{array}$ & $\begin{array}{c}\delta^{13} \mathrm{C} \\
(\%)\end{array}$ & Lab. Code ${ }^{* 2}$ \\
\hline \multirow[t]{3}{*}{ UDA1 } & $65-66$ & plant remain & $2,780 \pm 40$ & 2,778 to 2,966 & 2,872 & -25.4 & Beta-200528 \\
\hline & $156-157$ & bulk & $4,580 \pm 50$ & 5,048 to 5,459 & 5,254 & -29.2 & Beta-200529 \\
\hline & $200-201$ & bulk & $6,980 \pm 40$ & 7,702 to 7,929 & 7,816 & -28.1 & Beta-197967 \\
\hline \multirow[t]{6}{*}{ UDA2 } & $35-36$ & plant remain & $2,760 \pm 20$ & 2,785 to 2,922 & 2,854 & -19.2 & UCIAMS-21238 \\
\hline & $131-132$ & bark & $4,605 \pm 20$ & 5,298 to 5,445 & 5,372 & -25.1 & UCIAMS-21243 \\
\hline & $131 \cdot 132$ & bark & $4,235 \pm 20$ & 4,712 to 4,852 & 4,782 & -25.2 & UCIAMS-21245 \\
\hline & $132-133$ & bark & $4,480 \pm 20$ & 4,988 to 5,287 & 5,138 & -22.6 & UCIAMS-21236 \\
\hline & $179-180$ & peat & $7,190 \pm 40$ & 7,938 to 8,154 & 8,046 & -29.1 & Beta-197966 \\
\hline & 259 & bark & $10,160 \pm 25$ & 11,714 to 11,986 & 11,850 & -22.3 & UCIAMS-21230 \\
\hline
\end{tabular}

${ }^{*} 1$ Ages adapted for sediment accumulation rate ${ }^{*} 2$ Beta: Beta Analytic Inc.

*2 UCIAMS: W. M. Keck Carbon Cycle Accelerator Mass Spectrometry Laboratory (measured by H. Kitagawa, Nagoya Univ.). 
Table 3 Petrographic properties of tephra samples for UDA1 and UDA2 cores

\begin{tabular}{|c|c|c|c|c|c|c|c|}
\hline Site & $\begin{array}{c}\text { Depth } \\
(\mathrm{cm})\end{array}$ & Heavy mineral ${ }^{\text {"' }}$ & $\begin{array}{c}\text { Volcanic } \\
\text { glass } \\
\text { type } \\
\end{array}$ & $\begin{array}{l}\text { Refractive index } \\
\text { of volcanic glass } \\
\text { (mean) }\end{array}$ & $\begin{array}{c}\text { Count } \\
\text { number of } \\
\text { grass shard }\end{array}$ & Tephra & $\begin{array}{c}\text { Age } \\
\text { (cal BP) }\end{array}$ \\
\hline \multirow[t]{4}{*}{ UDA1 } & $17-18$ & $\mathrm{Opq}>\mathrm{Opx}>\mathrm{GHb}>\mathrm{Cpx}$ & pumice & $1.495-1.498(1.497)$ & 2 & unknown & - \\
\hline & & & & $1.502-1.504(1.503)$ & 44 & $\mathrm{Ma}-\mathrm{b}$ & $903^{* 2}$ \\
\hline & & & & $1.508-1.511(1.509)$ & 21 & $\mathrm{~B}-\mathrm{Tm}$ & $1,013(\mathrm{AD} 937)^{* 3}$ \\
\hline & & & & $1.520-1.522(1.521)$ & 11 & $\mathrm{~B}-\mathrm{Tm}$ & $1,013(\mathrm{AD} 937)^{* 3}$ \\
\hline \multirow[t]{4}{*}{ UDA2 } & $14-15$ & $\mathrm{Opx}>\mathrm{Cpx}>\mathrm{Opq}$ & pumice & $1.489-1.495(1.491)$ & 65 & $\mathrm{Ta} \cdot \mathrm{a}$ & $211(\mathrm{AD} 1739)^{* 4}$ \\
\hline & & & & $1.502-1.503(1.503)$ & 8 & $\mathrm{Ma} \cdot \mathrm{b}$ & $903^{* 2}$ \\
\hline & & & & $1.509-1.510(1.509)$ & 3 & $\mathrm{~B}-\mathrm{Tm}$ & $1,013(\mathrm{AD} 937)^{\star 3}$ \\
\hline & & & & $1.520-1.521(1.520)$ & 2 & $\mathrm{~B}-\mathrm{Tm}$ & $1,013(\mathrm{AD} 937)^{{ }^{3} 3}$ \\
\hline
\end{tabular}

*1 Opx, Cpx: orthopyroxene, clinopyroxene, GHb: green hornblende, Opq: opaque mineral.

*2 Median calibrated age based on $980 \pm 100$ yrs BP by Katsui et al. (1975), *3 Fukusawa et al. (1998), *4 Soya (1972).

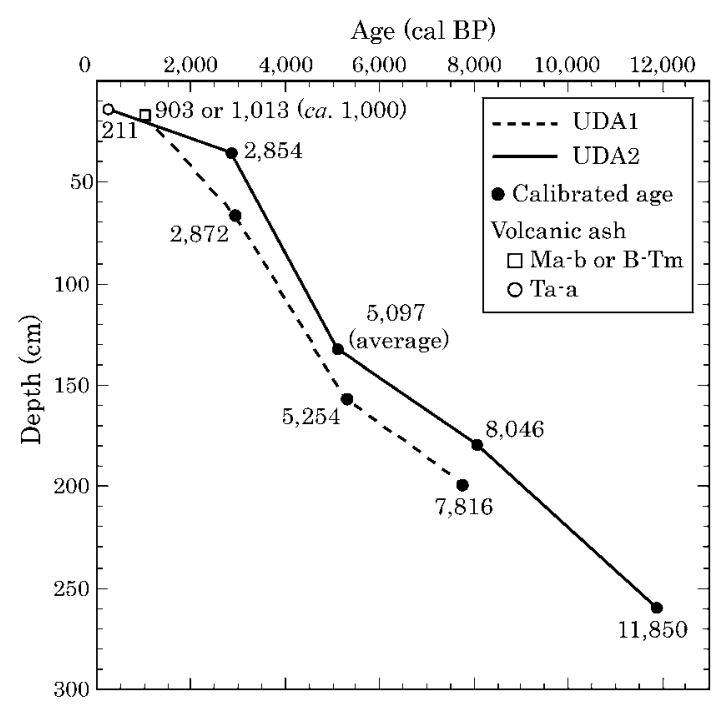

Fig. 2 Age-depth curves for UDA1 and UDA2 cores based on calibrated radiocarbon dates and ages of volcanic ashes

face samples and core samples was carried out by a procedure slightly modified from Eguchi (1996). Phytoliths were extracted from $1 \mathrm{~cm}^{3}$ samples after organic matter oxidation using $30 \% \mathrm{H}_{2} \mathrm{O}_{2}$, calcium carbonate removal using $3 \mathrm{~N}^{-}$ $\mathrm{HCl}$, and clay removal according to Stoke's law. Prior to extraction, a known amount of glass beads, which were $45 \mu \mathrm{m}$ in diameter, were added to each sample to estimating the phytolith concentration (according to Fujiwara, 1976). Phytoliths were mounted on microscope slides in Eukitt mounting medium. Microscopic observations were performed at $400 \times$ magnification, and more than 200 phytoliths were counted from each sample.

Identification of Gramineae phytoliths were based on Sase and Kondo (1974), Sugiyama and Fujiwara (1986), and Kondo and Ootaki (1992). Conifer trees belonging to Pinaceae produce a characteristic phytolith type. Cubic shaped phytoliths with bordered pits are produced in transfusion tracheid cells of the leaves of Pinaceae (Klein and Geis, 1978 ; Kondo et al., 2003). Kondo et al. (2002) examined the classification of Pinaceae trees below genus level focusing on the size of the bordered pits on phytoliths from transfusion tracheid cell in Pinaceae leaves. However, the size of the bordered pits on the transfusion tracheid phytoliths which were extracted from the fossil assemblages used in this study could not be measured because the shape of the bordered pits was not clear. Therefore, transfusion tracheid phytoliths were classified as Pinaceae type phytolith in this study. We also referred to the reference phytoliths collection obtained from major plant species common to the region. In this study, we endeavored to follow the phytolith nomenclature described by the International Code for Phytolith Nomenclature (ICPN WORKING GROUP, 2005) and Kondo (2004) wherever possible.

\section{Results}

\section{Modern phytolith assemblages}

The modern phytolith assemblages from forest stands on the Dorokawa Mire are shown in Figure 3. Percentages for each phytolith type were calculated based on the total phytolith 
counts including unidentified types.

The phytolith assemblages from the surface samples both in the P. glehnii stands and hardwood stands show a significant proportion of dwarf bamboo type phytoliths (sum of the Sasa or Bambusoideae type bulliform cells and Bam- busoid type short cells) which were derived from dwarf bamboo (Fig. 4). The percentage values of the dwarf bamboo type phytoliths from the P. glehnii stands are $54.5 \pm 4 \%$, and that of hardwood stands are $48.5 \pm 4 \%$. The sum of each percentage value of the phytolith morphotypes

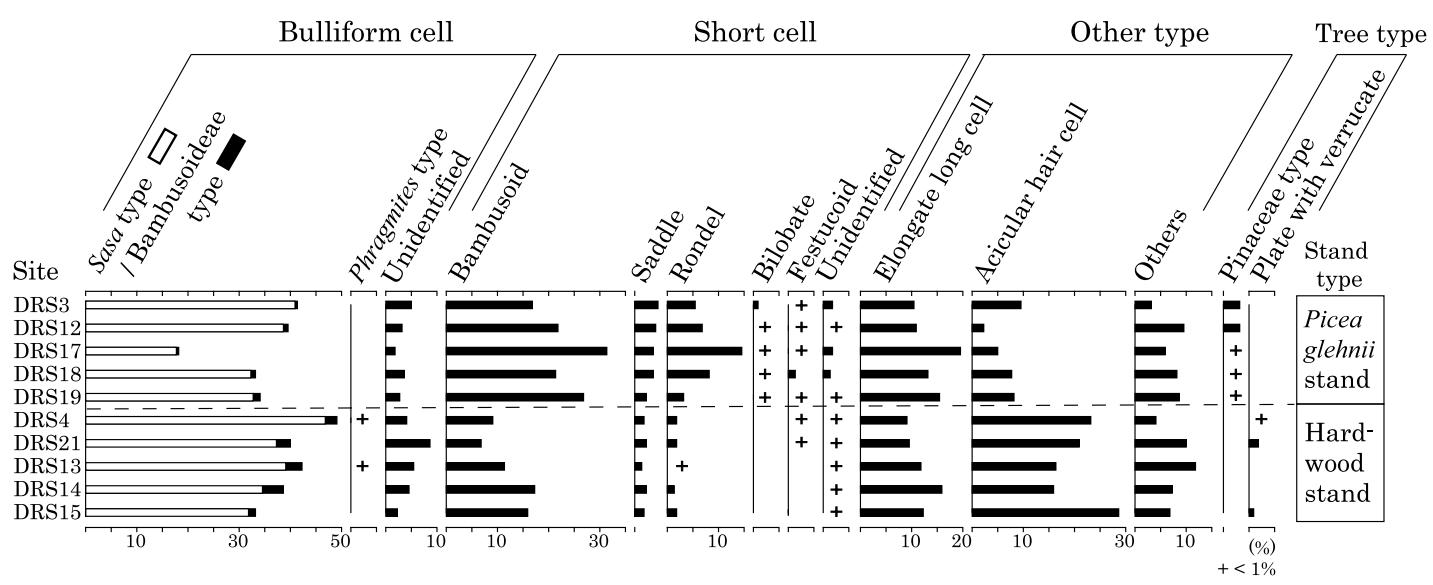

Fig. 3 Percentages of phytolith morphotypes from the surface samples in forest stands on the Dorokawa Mire
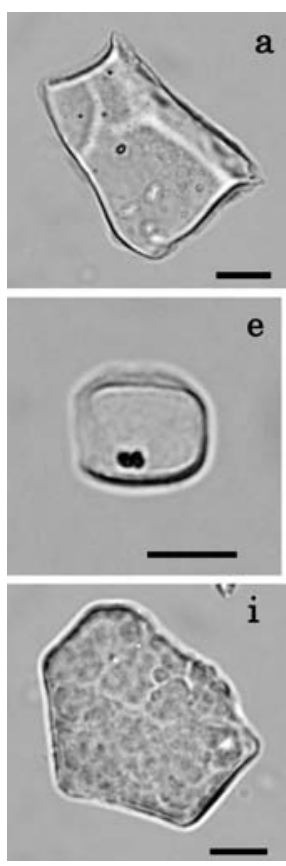

b
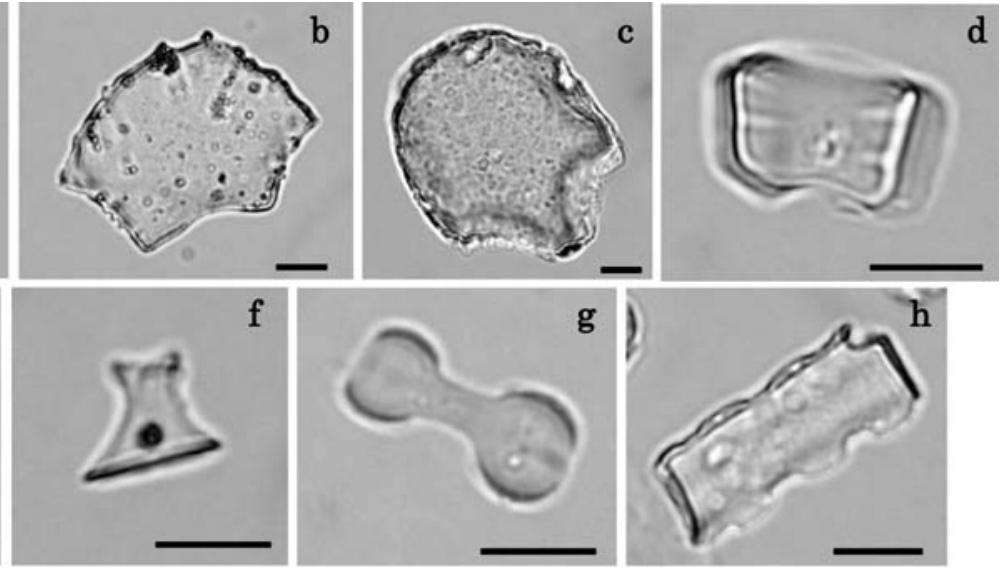

g
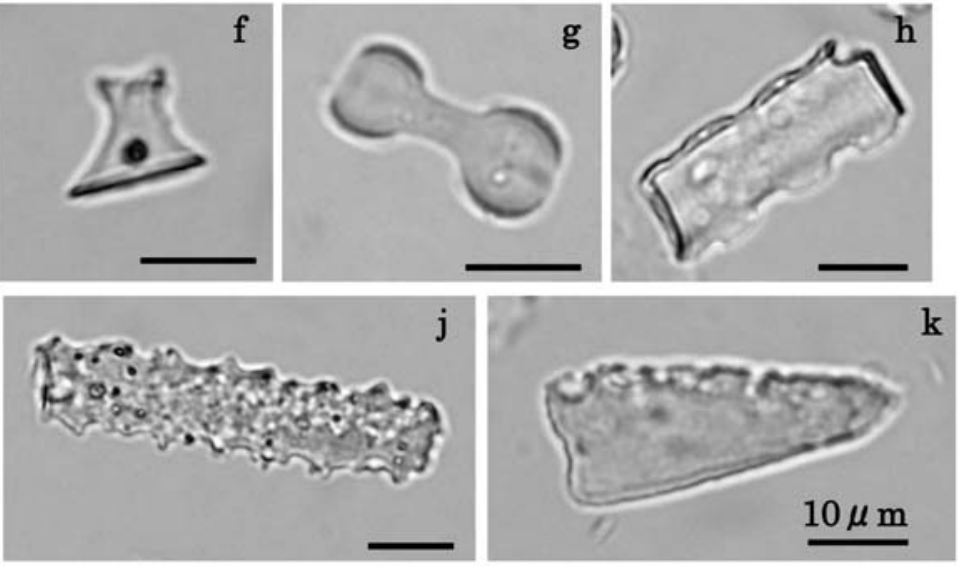

Fig. 4 Phytolith morphotypes from modern and fossil assemblages on the Dorokawa Mire a : Pinaceae type (transfusion tracheid cell), b : Sasa type (bulliform cell), c : Phragmites type (bulliform cell), d : Bambusoid (short cell), e : Saddle (short cell), f : Rondel (short cell), g : Bilobate (short cell), h : Festucoid (short cell), i : Plate with verrucate-type, $\mathrm{j}$ : Elongate long cell, k : Acicular hair cell. 
which are common in dwarf bamboo and other Gramineous species (Fig. 4 : saddle, rondel, elongate, and aciculate hair cells), and the percentage values of the dwarf bamboo type phytoliths mentioned above, add up to $85.2 \%$ and 83.4\% in P. glehnii stands and hardwood stands, respectively. On the other hand, phytolith assemblages from the P. glehnii stands are characterized by the presence of Pinaceae type phytoliths (Fig. 4 : transfusion tracheid cell), although with low percentage values (3.3 to $0.1 \%$ ). In addition, phytolith assemblages from the hardwood stands are characterized by the presence of Phragmites type bulliform cells and plate with verrucate-type phytoliths (Fig. 4). On the basis of the reference phytolith collection mentioned above, the plate with verrucate-type phytoliths are found only in the leaves of hardwood trees (e.g. Ulmus davidiana var. japonica).

According to the transect sampling of surface soils (Fig. 5), phytolith assemblages represent a relatively high amount of Pinaceae type phytoliths (3.5\%) just below the crown of one of the margin of $P$. glehnii stand $(0 \mathrm{~m}$ point). However, 10 and $20 \mathrm{~m}$ distant samples from the stand margin of $P$. glehnii show the low percent-

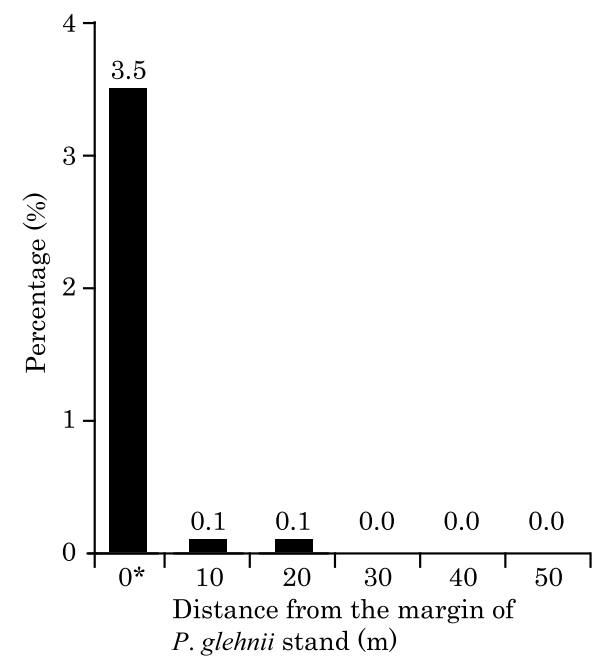

Fig. 5 Pinaceae type phytolith percentages of the surface samples from the margin of the P. glehnii stand to dwarf bamboo grassland (*just below the crown of $P$. glehnii)

Percentage values were calculated based on the total phytolith counts including unidentified types. ages of the Pinaceae type phytoliths (0.1\%), and this type of phytolith is absent from area over $30 \mathrm{~m}$ away.

\section{Fossil phytolith assemblages}

Figure 6 shows the phytoliths frequencies from the UDA1 and the UDA2 cores, respectively. Percentage values for each phytolith morphotype were calculated based on the total phytolith counts including unidentified types. These diagrams were divided into four local phytolith zones, respectively, based on significant changes in the phytoliths characteristics.

UDA1 site (Fig. 6-A)

UDA1-1 zone ( $c a .8,000$ to $5,000 \mathrm{cal} \mathrm{BP})$ : The assemblages of this zone are characterized by the occurrence of Phragmites type bulliform cell phytoliths. Also, dwarf bamboo type phytoliths are represented in minor proportions (maximum 13\%).

UDA1-2 zone (ca. 5,000 to 3,000 cal BP) : Phragmites type bulliform phytoliths are absent in this zone, whereas the dwarf bamboo type phytoliths increased.

UDA1-3 zone ( $c a$. 3,000 to $1,500 \mathrm{cal} \mathrm{BP})$ : The phytoliths are extremely poor in this zone.

UDA1-4 zone ( $c a .1,500 \mathrm{cal}$ BP to present) : The phytoliths from dwarf bamboo increase again. Also, the bilobate type phytoliths which belongs to the Panicoideae or Arundinoideae subfamily and the Festucoid type phytoliths which belongs to the Pooideae subfamily are relatively abundant (3.8 and $3.2 \%$, respectively) in the beginning of this zone. The Pinaceae type phytoliths begin to occur with low percentages $(<1 \%)$ at the mid part of this zone. In this zone, the percentage values of dwarf bamboo type phytoliths are high $(>50 \%)$, with an abrupt increase of the phytolith accumulation rate.

\section{UDA2 site (Fig. 6-B)}

UDA2-1 zone ( $c a$. 12,000 to 10,000 cal BP) : The assemblages are characterized by a relatively high amount of Festucoid type phytoliths (mean $4.2 \%)$ and a predominance of elongate long cell (mean 47.6\%) and acicular hair cell (mean 17.7\%) phytoliths. No dwarf bamboo type phytoliths were counted in the assemblages.

UDA2-2 zone ( $c a$. 10,000 to 4,500 cal BP) : The assemblages of this zone show the continuous occurrence of Phragmites type bulliform phytoliths. The dwarf bamboo type phytoliths also 

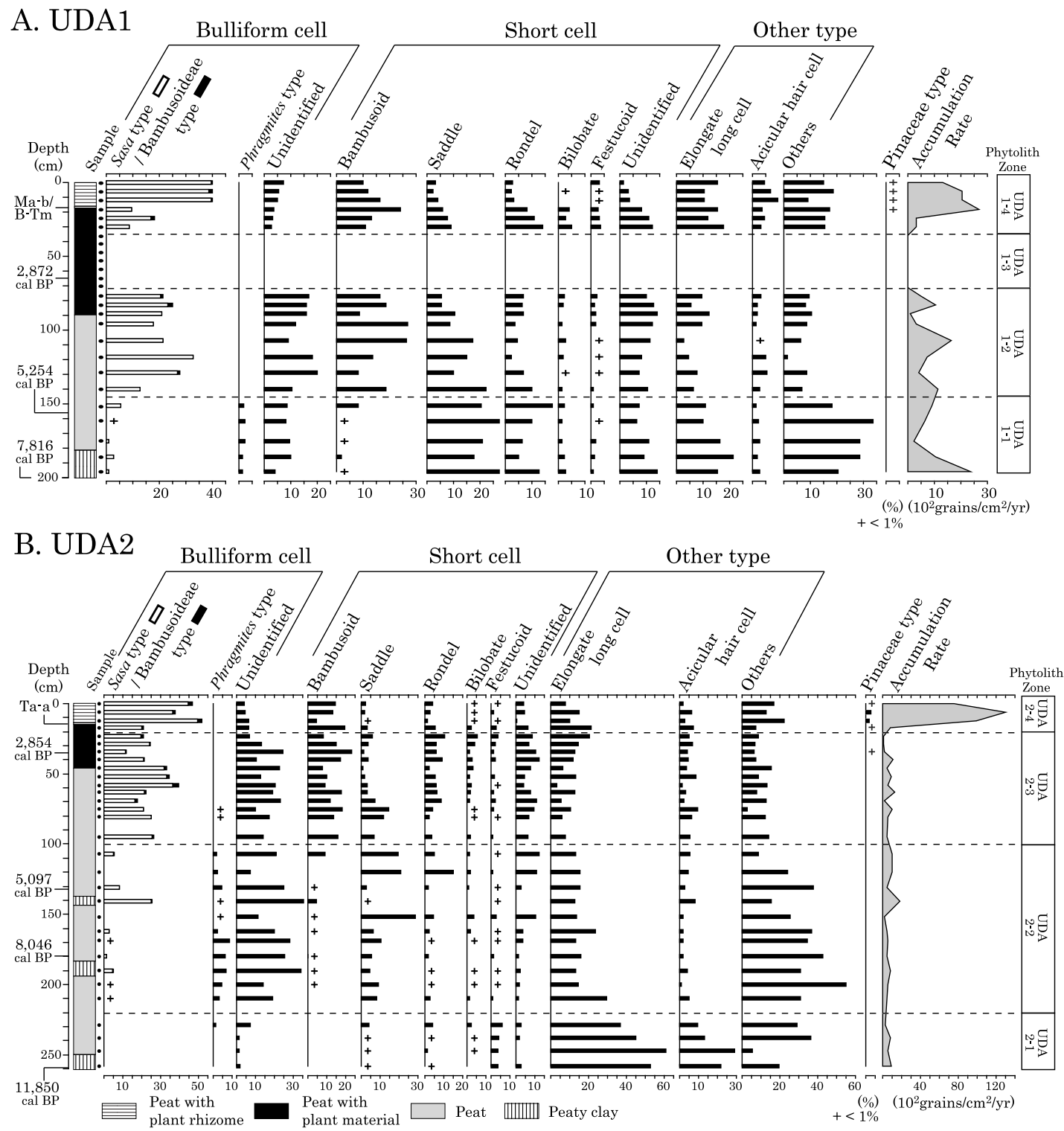

Fig. 6 Percentages of phytolith morphotypes and phytolith accumulation rate from the UDA1 (A) and the UDA2 (B) cores

begin to occur.

UDA2-3 zone ( $c a$. 4,500 cal BP to below Ta-a tephra layer): The phytolith assemblages are characterized by the absence of Phragmites type bulliform phytoliths and a high percentage of dwarf bamboo type phytoliths (mean 36.6\%). The percentage values of the bilobate and Festucoid type phytoliths also slightly increase in this zone.
UDA2-4 zone (below Ta-a tephra layer to present): The phytolith assemblages present the continuous occurrence of Pinaceae type phytoliths $(0.4$ to $2.6 \%)$. The phytolith accumulation rate and the percentage values of the dwarf bamboo type phytoliths show an abrupt increase simultaneously.

\section{Discussion}




\section{Interpretation of modern phytolith as- semblages}

Phytolith assemblages from surface samples in different vegetation sites were made clear for the interpretation of fossil phytolith assemblages in this study. As shown in Figure 5, transect modern phytolith assemblages showed the short dispersal distance (maximum $20 \mathrm{~m}$ ) for Pinaceae type phytoliths supplied from the margin of P. glehnii stand. Also, as shown in Figure 3, Pinaceae type phytoliths characteristically occurred only from the surface samples collected in P. glehnii dominated stands, although with low percentage values (maximum 3.3\%). Three pinaceous species (P. glehnii, $P$. jezoensis and Abies sachalinensis) exist on and around the Dorokawa Mire today. The conifer stands established on the mire are composed only of P. glehnii among them. The habitats of these three pinaceous species can be explained by their ecological features. P. glehnii can establish a community in a wet and oligotrophic environment (Tatewaki, 1943 ; Matsuda, 1989), while $A$. sachalinensis and $P$. jezoensis establish communities on fertile and mesic soil conditions (Kojima, 1983 ; Natsume, 1985 ; Nishijima et al., 1997). Judging from the dispersal pattern of the Pinaceae type phytolith and ecological feature of P. glehnii, the Pinaceae type phytoliths from the sediment samples in the Dorokawa Mire indicate the existence of P. glehnii in the site.

On the other hand, through all surface samples from both conifer stands and hardwood stands with dense undergrowth of dwarf bamboo, the dwarf bamboo type phytoliths (sum of the Sasa or Bambusoideae type bulliform cells and Bambusoid type short cells) occurred with high percentage values (almost 50\%), while the Pinaceae type phytoliths occurred only in the samples from the conifer stands with low percentage values (Fig. 3). Thus, the surface samples under the dense dwarf bamboo include considerable dwarf bamboo type phytoliths in spite of the samples from $P$. glehnii dominated stands. For this reason it seems that the abundance of Pinaceae trees is underestimated in comparison with that of dwarf bamboo in phytolith analysis.

Plate with verrucate-type phytoliths were also found only in surface samples collected in hardwood stands. Therefore, this phytolith morphotype possibly indicates the existence of hardwood trees in the local site. However, this phytolith morphotype did not occur from fossil assemblages analyzed in this study. Thus, there is a possibility that the hardwood dominated stands which provide the plate with verrucatetype phytoliths have not been established in the core sampling sites since the early-Holocene.

With regard to pollen analysis, which is main tool for the palaeoecological study, it has following defects. There are some difficulties to define the pollen source area. Also, identification of Gramineae pollen, which includes dwarf bamboo, reed and many kinds of grasses, is restricted to the family level. On the other hand, phytolith assemblages reflect stand-scale vegetation composed of Pinaceae trees as mentioned above (Figs. 3 and 5). In addition, some types of Gramineae phytoliths can be identified at subfamily or genus level such as Pooideae, dwarf bamboo and reed. Thus, phytolith analysis can contributes to reconstruction of stand-scale vegetation composed mainly of Gramineae and Pinaceae species. The data from modern phytolith assemblages will make it possible to interpret fossil phytolith assemblages.

\section{Vegetation history during the Holocene}

The following vegetation history since the early-Holocene ( $c a$. 12,000 cal BP to present) in the study sites on the Dorokawa Mire is reconstructed based on the results of phytolith records for the UDA1 and UDA2 cores (Fig. 6) and the modern analogue of phytoliths (Figs. 3 and 5). Summarized vegetation history is illustrated in Figure 7.

Early-Holocene (ca. 12,000 to 10,000 cal BP)

This period which can be correlated with the UDA2-1 zone is characterized by the occurrence of Festucoid type phytoliths derived from Pooideae grasses, and high percentages of elongate long cell and acicular hair cell phytoliths. The modern distribution pattern of Gramineae in the Japanese archipelago is characterized by two types of Gramineae subfamilies along the latitudinal gradient (Takeda et al., 1985) : the higher latitude with cool temperate zone is characterized by the distribution of the 


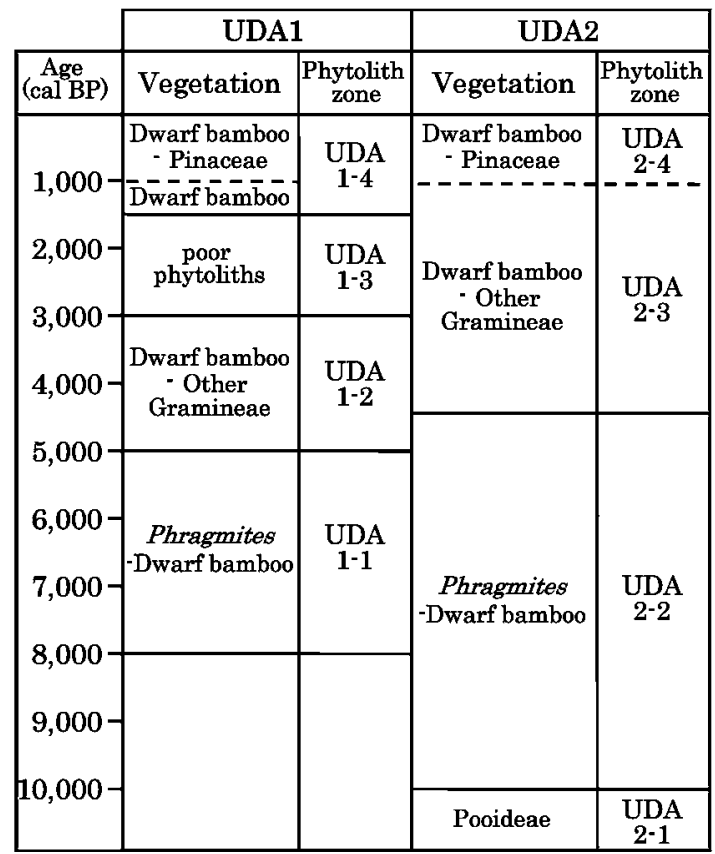

Fig. 7 Summarized vegetation history at the Picea glehnii stands on the Dorokawa Mire during Holocene

Festucoideae (Pooideae) subfamily which produces the Festucoid type phytolith, and the lower latitude with warm temperate zone is characterized by the relative abundance of the Panicoideae subfamily which produces the bilobate type phytolith. In addition, Sase and Hosono (1999) reported that the Festucoid type phytolith occurred with relatively high percentages of elongate long cells and acicular hair cells among other types of phytoliths, because the Pooideae subfamily produces a large amount of both types of phytoliths. Our results from the UDA2-1 zone are in agreement with the phytoliths composition reported by the previous study mentioned above. According to the pollen records of the Kenbuchi basin, which is $c a .50 \mathrm{~km}$ from the Dorokawa Mire, a taiga forest composed of Larix and Picea which had dominated in the last glacial still remained around the site until early-Holocene (Igarashi et al., 1993). Therefore, the occurrence of the Festucoid type phytolith during the UDA2-1 zone indicates the existence of Pooideae-dominated vegetation reflecting the cool climate.
The sediments of the UDA2-1 zone changed gradually from peaty clay to peat. This change and occurrence of Festucoid type phytolith imply the formation of herbaceous community dominated by Pooideae species (e.g. Calamagrostis langsdorffii) under wet conditions.

Early to mid-Holocene (ca. 10,000 to 5,000 cal BP)

In UDA2-2 zone ( $c a$. 10,000 to 4,500 cal BP), phytolith morphotypes including Pooideae grasses decreased to several percentage values and the Phragmites type bulliform phytolith occurred. Also, in UDA1-1 zone (ca. 8,000 to 5,000 cal BP), the occurrence of Phragmites type bulliform phytolith was recognized. These results imply that the reed spread around the study sites during the early to mid-Holocene. Dwarf bamboo type phytoliths also began to occur in this period. However, low plant abundance of dwarf bamboo is estimated because of the low percentage values of dwarf bamboo type phytoliths and low accumulation rate of phytoliths (Fig. 6).

Late-Holocene (ca. 5,000 to 1,500 cal BP)

At both the UDA1-2 (ca. 5,000 to 3,000 cal BP) and UDA2-3 (ca. 4,500 cal BP to below Ta-a tephra layer) zones, the phytolith records are characterized by the absence of Phragmites type bulliform cells and the high percentages of dwarf bamboo type phytoliths. Takakuwa and Ito (1986) suggested that the dwarf bamboo invasion into the mire indicates the aridification of the mire. Therefore, the replacement of the Phragmites by dwarf bamboo indicates that the aridification of the mire progressed during this period. However, although there were high percentage values of the dwarf bamboo type phytoliths in these zones, the phytolith accumulation rates of these zones are actually lower than that of modern level (upper part of UDA14 and UDA2-4 zones), in which dwarf bamboo forms a dense community. Therefore, the distribution of dwarf bamboo during this period may be scattered.

It should be mentioned here that quite low concentrations of phytoliths from $c a$. 3,000 to $1,500 \mathrm{cal} \mathrm{BP}$ at the UDA1-3 zone. The cause of the low concentrations of phytoliths may be the development of a plant community which produced no phytoliths. At the UDA1-3 zone, 
the peat with plant materials was composed mainly of fragments of Sphagnum sp. Therefore, Sphagnum covered vegetation would have been established on the UDA1 site during this period. However, at the upper part of the UDA 2-3 zone corresponding to the UDA1-3 zone, the dwarf bamboo type phytoliths occurred continuously in spite of the low phytolith accumulation rate. Thus, the differences of phytoliths composition between the UDA1and UDA2 sites may indicate the differences of local vegetation features.

\section{After ca. 1,500 cal BP}

At the beginning of the UDA1-4 zone ( $c a$. $1,500 \mathrm{cal} \mathrm{BP}$ ) and of the UDA2-4 zone (below Taa tephra layer : older than $c a .200 \mathrm{cal}$ BP), dwarf bamboo increased abruptly and has been sustained to the present. Moreover, Pinaceae type phytoliths began to occur at both the mid part of the UDA1-4 zone ( $c a .1,000 \mathrm{cal} \mathrm{BP})$ and the beginning of the UDA2-4 zone. Taking into account the ecological features of pinaceous trees mentionsd above, the Pinaceae type phytoliths extracted from the UDA1-4 and UDA24 zones indicate the appearance of $P$. glehnii. Therefore, $P$. glehnii trees would have existed at least $c a$. 1,000 cal BP in the study sites.

\section{Dynamics of dwarf bamboo and estab- lishment of Picea glehnii stands}

As shown in Figure 6, Pinaceae type phytoliths occurred continuously from the mid part of the UDA1-4 zone ( $c a .1,000 \mathrm{cal} \mathrm{BP}$ ) and the beginning of the UDA2-4 zone (older than $c a$. $200 \mathrm{cal}$ BP). It indicates that the appearance of $P$. glehnii was not temporary but successive on the study sites. Therefore, the P. glehnii stands would have been established in the study sites by $c a$. 1,000 cal BP at least.

Also, it should be pointed out here that the Pinaceae type phytoliths have been detected in the upper part of the UDA2-3 zone ( $c a .2,700 \mathrm{cal}$ $\mathrm{BP})$. The occurrence of the Pinaceae type phytoliths at this time possibly reflects the temporary invasion of $P$. glehnii on the UDA2 site. The Pinaceae type phytoliths occurred continuously although with low frequencies from the beginning of the UDA2-4 zone. Therefore, the time of the establishment of P. glehnii stand in the UDA2 site may correspond to the boundary between the UDA2-3 and UDA2-4 zones.
Although dwarf bamboo began to invade into the study sites at $c a$. 5,000 cal BP (beginning of the UDA1-2 and UDA2-3 zones), the density of dwarf bamboo in that time was lower than that during the period between $c a$. 1,500 cal BP and present, because of the relative low phytolith accumulation rates in the UDA1-2 and UDA23 zones (right hand diagram in Fig. 6). Afterwards, however, dwarf bamboo increased abruptly at the beginning of the UDA1-4 zone and of the UDA2-4 zone. Also, the Pinaceae type phytoliths occurred continuously from the mid part of the UDA1-4 zone and the beginning of the UDA2-4 zone. Consequently, the $P$. glehnii dominated stands were established at the same time or a little bit later when the dwarf bamboo increased abruptly in the study sites. It indicates that the $P$. glehnii stands would have had dense undergrowth of dwarf bamboo since the establishment of the stands.

It can be summarized for the establishment of the P. glehnii stands with dense undergrowth of dwarf bamboo as follows. Dwarf bamboo began to invade into the study sites at $c a .5,000$ calBP owing to the aridification of the mire. After ca. 1,000 cal BP, P. glehnii invaded into the study sites where the dwarf bamboo had been dominant. Then, the P. glehnii stands with dense undergrowth of dwarf bamboo has been established. In this study, we made clear by the phytolith analysis that $P$. glehnii stands had not been established before the establishment of dwarf bamboo thickets. It suggests that the regeneration of $P$. glehnii occurred under the dominance of the dwarf bamboo. At present, establishment of almost seedlings and saplings of P. glehnii on the Dorokawa Mire are restricted on fallen logs or stump area where the coverage of dwarf bamboo is low. The dense undergrowth of dwarf bamboo has negative effects on regeneration of $P$. glehnii, because the dwarf bamboo thickets form dark conditions and thick litter accumulation (Makita, 1992 ; Maruyama et al., 2004). Therefore, taking our findings into consideration with the regeneration behavior of $P$. glehnii, the fallen log regeneration by some disturbances would have been continued in these stands. The P. glehnii stands with dwarf bamboo understory are considered to have been maintained since $c a$. 1,000 
cal BP on the study sites by this way of regeneration.

As noted above, this study demonstrated that the phytolith analysis is a useful method for reconstructing the stand-scale vegetation with dwarf bamboo understory. Although the phytolith records of this study reflect the local vegetation history at the $P$. glehnii stands, a combination of the phytolith data and pollen data from future studies will be able to offer both the local and regional vegetation changes in and around the Dorokawa Mire.

\section{Conclusion}

This study clarified the Holocene vegetation history in the $P$. glehnii stands on the Dorokawa Mire, with special focus on the dynamics of the Gramineae, which includes dwarf bamboo, and the establishment of $P$. glehnii stands based on the modern and fossil phytolith assemblages. Modern phytolith assemblages show that the short dispersal distance of the Pinaceae type phytolith (maximum $20 \mathrm{~m}$ ). Also, the occurrence of this phytolith morphotype indicates that the existence of P. glehnii in the study site. Fossil phytolith assemblages show that the Pooideae-dominated vegetation, which reflects the cool climate, distributed during the early-Holocene ( $c a .12,000$ to 10,000 cal BP). The low-moor with Phragmites (reed) spread on the study sites from the early to mid-Holocene ( $c a$. $10,000$ to $5,000 \mathrm{cal} \mathrm{BP})$. The reed was replaced by dwarf bamboo at $c a$. 5,000 cal BP. The $P$. glehnii dominated stands would have been established at the same time or a little bit later when the dwarf bamboo formed dense community in the study sites ( $c a$. 1,000 cal BP). Some disturbances probably have provided suitable sites, such as fallen logs, for regeneration of $P$. glehnii under the dwarf bamboo thickets.

\section{Acknowledgements}

We thank Dr. Hiroyuki Kitagawa of Nagoya University for the AMS ${ }^{14} \mathrm{C}$ datings. Also, we are grateful to technical stuff of the Uryu experimental forest of Hokkaido University for their technical support in the fieldworks. Masato Makino, Goh Kishimoto, Takuma Nakamura, Michiharu Igaki and Koji Uenae of Kyoto Prefectural Univeristy and Fumitaka Katamura of
Hokkaido University are also acknowledged for their help in the fieldworks. We thank the colleagues and graduate students of the Laboratory of Forest Community Dynamics, Kyoto Prefectural University, who gave us helpful comments on earlier version of the manuscript. This study was conducted as part of the 5-2 IDEA project (Interactions between the Environmental Quality of a Watershed and the Environmental Consciousness : Project leader, Dr. Takahito Yoshioka) of the Research Institute for Humanity and Nature. This study was also supported partly by the Sasakawa Scientific Research Grant from the Japan Science Society.

\section{References}

Eguchi, S. (1996) Laboratory analysis of phytolith. Kanto Plain, 4, 25-28. (J)

Eguchi, S. (1998) Distribution of opal phytoliths and their mother plants in the coastal zone of Japan. Japanese Journal of Ecology, 48, 245-255. (J+E)

Field Science Center for Northern Biosphere, Hokkaido University, Forest Research Station Database (unpublished data) Internet address for data (URL) : http : //www.hokudai.ac.jp/forest/ (J)

Fujiwara, H. (1976) Fundamental studies of plant opal analysis - On the silica bodies of moter cell of rice plants and their near relatives, and the method of quantitative analysis. Archaeology and Natural Science (Biannual Journal of the Japanese Society for Scientific Studies on Cultural Property), 9, 15-29. (J $+\mathrm{E})$

Fukusawa, H., Tsukamoto, S., Tsukamoto, H., Ikeda, M., Okamura, M. and Matsuoka, H. (1998) Falling age of Baegdusan-Tomakomai tephra (B-Tm) estimated by using non-glacial varves. LAGUNA, 5, 55-62. (J $+\mathrm{E})$

Hiura, T., Sano, J. and Konno, Y. (1996) Age structure and response to fine-scale disturbances of Abies sachalinensis, Picea jezoensis, Picea glehnii, and Betula ermanii growing under the influence of a dwarf bamboo understory in northern Japan. Canadian Journal of Forest Research, 26, 289-297.

ICPN WORKING GROUP : Madella, M., Alexancre, A. and Ball, T. (2005) International code for phytolith nomenclature 1.0. Annals of Botany, 96, 253-260.

Igarashi, Y. (1994) Quaternary forest and climate history of Hokkaido, Japan, from marine sediments. Quaternary Science Reviews, 13, 335-344.

Igarashi, Y., Igarashi, T., Daimaru, H., Yamada, O., Miyagi, T., Matsushita, K. and Hiramatsu, K. (1993) Vegetation history of Kenbuchi basin and Furano basin in Hokkaido, north Japan, since 32,000 yrs BP. The Quaternary Research (Daiyonki-Kenkyu), 32, 89-105. $(\mathrm{J}+\mathrm{E})$

Igarashi, Y., Igarashi, T., Endo, K., Yamada, O., Naka- 
gawa, M. and Sumita, M. (2001) Vegetation history since the late glacial of Habomai bog and Ochiishi Cape bog, Nemuro peninsula, eastern Hokkaido, north Japan. Japanese Journal of Historical Botany, 10, 67-79. (J+E)

Igarashi, Y. and Takahashi, N. (1985) Origin and vegetational succession of upland bogs in the Daisetsu Mountains, central Hokkaido (I). The Quaternary Research (Daiyonki-Kenkyu), 24, 99-109. (J+E)

Kariya, Y., Sugiyama, S. and Sasaki, A. (2004) Changes in opal phytolith concentrations of Bambusoideae morphotypes in Holocene peat soils from the pseudoalpine zone on Mount Tairappyo, central Japan. The Quaternary Research (Daiyonki-Kenkyu), 43, 129-137.

Katsui, Y., Ando, S. and Inada, K. (1975) Formation and magmatic evolution of Mashu volcano, east Hokkaido, Japan. Journal of the Faculty of Science, Hokkaido University, series IV, 16, 533-552.

Kawano, T., Kawano, K., Udatsu, T. and Fujiwara, H. (2006) Relationship between modern tree phytolith assemblages and tree composition in lucidophyllous forests in the southern part of Miyazaki prefecture. Japanese Journal of Historical Botany, 14, 3-14. $(\mathrm{J}+\mathrm{E})$

Klein, R. and Geis, J. (1978) Biogenic silica in the Pinaceae. Soil Science, 126, 145-156.

Kojima, S. (1983) Phytogeocoenoses of the montane Abies sachalinensis biogeoclimatic zone in Kitakami district, Hokkaido, Japan. I. Analysis of coniferous forest phytogeocoenoses. The Journal of the College of Liberal Arts, Toyama University. Natural Science, 16, 173-281.

Kondo, R. (1988) Soil genesis and ages of soils from the viewpoint of opal phytolith analysis. Pedologist, 32, 77-91. (J)

Kondo, R. (2004) Phytolith study. Pedologist, 48, 4664. (J).

Kondo, R., Oosawa, S., Tsutsuki, K., Tani, M. and Shibano, S. (2003) Characteristics of the opal phytoliths derived from Pinaceae leaves. Pedologist, 47, 90-103. $(\mathrm{J}+\mathrm{E})$

Kondo, R. and Ootaki, M. (1992) Opal phytoliths originated from the short cell in leaves of Bambusoideae. Reports of the Fuji Bamboo Garden, 36, 23-43. (J)

Kondo, R. and Sase, T. (1986) Opal phytoliths, their nature and application. The Quaternary Research (Daiyonki-Kenkyu), 25, 31-63. (J)

Kondo, R., Tsutsuki, K., Tani, M. and Maruyama, R. (2002) Differentiation of Genera Pinus, Picea, and Abies by the transfusion tracheid phytoliths of Pinaceae Leaves. Pedologist, 46, 32-35.

Makita, A. (1992) Survivorship of monocarpic bamboo grass, Sasa kurilensis, during the early regeneration process after mass flowering. Ecological Research, 7, 245-254.

Maruyama, R., Maruyama, M. and Konno, Y. (2004) Effects of understory vegetation and litter on the establishment of Abies sachalinensis and Picea jezoensis seedlings in a conifer forest in Hokkaido, northen Japan. Japanese Journal of Ecology, 54, 105-115. $(\mathrm{J}+\mathrm{E})$

Matsuda, K. (1989) Regeneration and growth in the Picea glehnii forest. Research Bulletins of the College Experiment Forests Hokkaido University, 46, 595-717. $(\mathrm{J}+\mathrm{E})$

Morita, Y. (2001) Vegetation history of Yururi Island in easternmost Hokkaido since the late glacial. Japanese Journal of Historical Botany, 10, 81-89. (J $+\mathrm{E})$

Nakashizuka, T. (1988) Regeneration of beech (Fagus crenata) after the simultaneous death of undergrowing dwarf bamboo (Sasa kurilensis). Ecological Research, 3, 21-35.

Narukawa, Y. and Yamamoto, S. (2002) Effects of dwarf bamboo (Sasa sp.) and forest floor microsites on conifer seedling recruitment in a subalpine forest, Japan. Forest Ecology and Management, 163, 61-70.

Natsume, S. (1985) Studies on the habitat conditions and early growth in the natural regeneration of Picea jezoensis CARR. Research Bulletins of the College Experiment Forests Hokkaido University, 42, 47-107. (J+E)

Nishijima, H., Iyobe, T., Nishio, F., Tomizawa, H. and Haraguchi, A. (1997) Distribution of Picea glehnii and Abies sachalinensis at Syunkunitai, and its relation to soil environment. Kushiro Ronshu, 29, 4152. $(\mathrm{J}+\mathrm{E})$

Reimer, PJ., Baillie, M., Bard, E., Bayliss, A., Beck, J., Bertrand, C., Blackwell, P., Buck, C., Burr, G., Cutler, K., Damon, P., Edward, R., Fairbanks, R., Friedrich, M., Guilderson, T., Hogg, A., Hughen, K., Kromer, B., McCormac, F., Manning, S., Ramsey, C., Reimer, R., Remmele, S., Southon, J., Stuiver, M., Talamo, S., Taylor, F., van der Plicht, J. and Weyhenmeyer, C. (2004) IntCal04 Terrestrial radiocarbon age calibration, 26-0 ka BP. Radiocarbon, 46, 1029-1058.

Sasaki, N., Kawano, T., Takahara, H. and Sugita, S. (2004) Phytolith evidence for the 700-year history of a dwarf-bamboo community in the sub-alpine zone of Mt. Kamegamori, Shikoku Island, Japan. Japanese Journal of Historical Botany, 13, 35-40.

Sase, T. and Hosono, M. (1999) The glacial-interglacial cycle record in phytolith assemblage of Tengutai tephra-soil section near Hachinohe, northern Japan. The Quaternary Research (Daiyonki-Kenkyu), 38, 353-364. $(\mathrm{J}+\mathrm{E})$

Sase, T. and Kondo, R. (1974) The study of opal phytoliths in the humus horizon of buried volcanic ash soils in Hokkaido. Research Bulletin of Obihiro University, 8, 465-483. ( $+\mathrm{E})$

Sase, T., Yamagata, K., Hosono, M. and Kimura, J. (2004) Phytolith records from tephra-soil sequence the last interglacial in the southern Ishikari lowland, Hokkaido, Japan : with special reference to the fluctuation of the Sasa group (dwarf bamboo) in paleo-vegetation. The Quaternary Research (Dai- 
yonki-Kenkyu), 43, 389-400. (J+E)

Soya, T. (1972) Formation of the Tarumae volcano. Bulletin of the Volcanological Society of Japan, 2 (16), 15-27. (J+E)

Stuiver, M., Reimer, PJ. and Reimer, R. (2005) CALIB 5.0.1 html. http : //www.calib.org

Sugiyama, S. and Fujiwara, H. (1986) The shape of silica bodies in the moter cells of Bambusoideae. Archaeology and Natural Science (Biannual Journal of the Japanese Society for Scientific Studies on Cultural Property), 19, 69-84. (J+E)

Takakuwa, J. and Ito, K. (1986) Ecological aspects of Sasa in mires. Memoirs of environmental science, Hokkaido University, 2, 47-65. (J+E)

Takeda, T., Tanikawa, T., Agata, W. and Hakoyama,
S. (1985) Studies on the ecology and geographical distribution of $\mathrm{C}_{3}$ and $\mathrm{C}_{4}$ grasses I. Taxonomic and geographical distribution of $\mathrm{C}_{3}$ and $\mathrm{C}_{4}$ grasses in Japan with special reference to climatic conditions. Japanese Journal of Crop Science, 54, 54-64. (J+E)

Tatewaki, M. (1943) Phytosociological study on the Picea glehnii forest. Research Bulletin of the College Experiment Forests, Hokkaido Imperial University, 13, 1-181. (J).

Tsukada, M. and Nakamura, J. (1988) Vegetationsgeschichte des Spätquartärs. Miyawaki, A. (ed.) Vegetation of Japan 9, Hokkaido : 96-130, Shibundo. (J)

$(\mathrm{J})$ in Japanese, $(\mathrm{J}+\mathrm{E})$ in Japanese with English abstract.

\title{
北海道北部泥川湿原のアカエゾマツ林域における 完新世の植物珪酸体群集の変遷
}

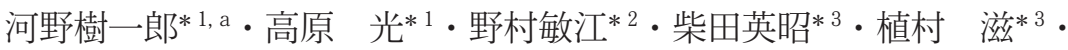 \\ 佐々木尚子*4 ・吉岡崇仁*4
}

\begin{abstract}
〔要旨〕
北海道北部の泥川湿原上に成立するアカエゾマツ林掞 よび落葉広葉樹林内から採取した表層試料, ならびにア カエゾマッ林内で採取した完新世の堆積物試料を用いて 植物珪酸体分析を行い，当湿原に扔けるササを中心之し たイネ科植生の変遷，およびアカエゾマツ林の成立時期 について検討した，堆積物の植物珪酸体分析の結果，約 $12,000 \sim 10,000$ 年前には, 泥川湿原上には寒冷気候下に 分布するイチゴッナギ覀科が生育する植生が成立してい た。その後約 $10,000 \sim 5,000$ 年前には，ヨシが生育する 湿潤な環境が広がっていたことが推測された。約 5,000 年前頃から, 調查地周辺ではヨシに代わってササが進入

を開始するが，この時期のササの分布はまだ散在する程 度であった，その後約 1,500 年前以降になるとササが急 増を始め，それ之ほぼ同時期かやや遅れてアカエゾマッ の侵入が認められた，表層試料の分析から，アカエゾマ ツに由来するマッ科型珪酸体はきわめて局所的なアカエ ゾマッの存在を反映することが明らかとなった。この結 果と堆積物試料の分析結果を組み合わせて見ると, 調査

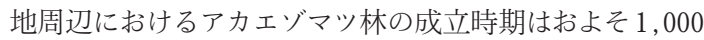
年前頃であると推測された。 また，その頃からすでにア カエゾマッ林は現在と同様なササ型林床を伴っていたと 考えられた
\end{abstract}

キーワード : アカエゾマツ林分, 完新世, ササ, 植物珪酸体, 表層試料

\footnotetext{
*1 京都府立大学大学院農学研究科 =606-8522 京都市左京区下鴨半木町 1-5.

*2 京都府立大学大学院農学研究科 (現住所: T381-2206 長野市青木島町綱島)。

*3 北海道大学北方生物圈フィールド科学センター $\mathbf{T} 096-0071$ 名寄市徳田 250 番地.

$* 4$ 総合地球環境学研究所 $\overline{\mathbf{T}} 603-8047$ 京都市北区上賀茂本山 457 番地 4.

*a Corresponding author : kawano@uf.kpu.ac.jp
} 